\title{
Aditivos e coadjuvante para a conservação de pães sem glúten do ponto de vista tecnológico
}

\section{Vitória C. V. Bellini, Yasmin C. de Queiroz, Gisela B. Silva, Caroline J. Steel}

\section{Resumo}

A crescente demanda por alimentos sem glúten vem impulsionando pesquisas para aprimorar esses produtos, sobretudo visando solucionar os problemas encontrados na conservação, relacionados ao fenômeno de staling (envelhecimento). Este estudo buscou caracterizar as matérias primas (composição centesimal) utilizadas na fabricação de pão sem glúten, e verificar o efeito de aditivos (monoglicerídeos, goma guar:xantana - mistura 1:1) e coadjuvante (enzima amilase maltogênica) na produção e conservação de pães sem glúten. Avaliou-se o volume específico no dia 1 e a textura nos dias $1,3,5,10$ e 15 do shelf life.

\section{Palavras-chave:}

monoglicerídeos, goma guar:xantana, enzima amilase maltogênica.

\section{Introdução}

A indústria de alimentos enfrenta desafios no que diz respeito a produtos sem glúten, e diversas estratégias têm sido adotadas para tentar solucionar problemas referente à sua conservação. O principal obstáculo encontrado está relacionado com o fenômeno de bread staling, responsável por perdas sensoriais e econômicas ${ }^{1}$.

Diversos aditivos têm sido usados visando retardar a retrogradação do amido e o envelhecimento, tais como goma guar e xantana, e monoglicerídeos. Também é utilizada a enzima amilase maltogênica, a qual retarda a retrogradação a partir da hidrólise de ligações glicosídicas ${ }^{2}$. Este estudo avalia a ação desses ingredientes na conservação de pães sem glúten.

\section{Materiais e Métodos}

\section{Caracterização das matérias primas:}

\begin{tabular}{c}
$\begin{array}{c}\text { Matérias primas: } \\
\text { farinha de arroz, } \\
\text { écula de mandioca, } \\
\text { albumina de ovo e mix } \\
\text { de farinhas }\end{array}$ \\
$\begin{array}{c}\text { Análises: umidade, } \\
\text { proteínas, cinzas, } \\
\text { lipídeos, } \\
\text { carboidratos }\end{array}$ \\
\hline
\end{tabular}

\section{Formulação e caracterização dos pães:}

\begin{tabular}{|c|c|}
\hline Mix de farinhas: & $\begin{array}{c}\text { Aditivos e coadjuvante: } \\
\text { monoglicerídeos }(0,25 \% \\
\text { e } 0,50 \%), \text { goma } \\
\text { fécula de mandioca, } \\
\text { farinha de arroz e } \\
\text { albumina de ovo } \\
0,5 a n t a n a) \text { e amilase } \\
0,50 \% \\
\text { maltogênica }(0,01 \% \text { e } \\
0,02 \%)\end{array}$ \\
\hline
\end{tabular}

Análises: volume

específico (dia 1) e textura do miolo

Dias 1, 3, 5, 10 e 15

\section{Resultados e Discussão}

Tabela 1. Composição centesimal das matérias primas

\begin{tabular}{cccc}
\hline Componente & $\begin{array}{c}\text { Fécula de } \\
\text { Mandioca }\end{array}$ & $\begin{array}{c}\text { Albumina } \\
\text { de Ovo }\end{array}$ & $\begin{array}{c}\text { Farinha de } \\
\text { Arroz }\end{array}$ \\
\hline Umidade \% & $11,41 \pm 0,22$ & $6,57 \pm 0,19$ & $9,70 \pm 0,27$ \\
Cinzas \% & $0,34 \pm 0,03$ & $3,80 \pm 0,43$ & $0,44 \pm 0,01$ \\
Lipídios \% & $0,56 \pm 0,03$ & $1,17 \pm 0,19$ & $1,35 \pm 0,10$ \\
Proteínas \% & $0,42 \pm 0$ & $86,33 \pm 1,10$ & $8,52 \pm 0,12$ \\
Carboidratos \%* & 87,27 & 2,13 & 79,99 \\
\hline
\end{tabular}

Tabela 2. Volume específico dos pães

\begin{tabular}{cc} 
Amostra & Vol. Espec. $(\mathrm{mL} / \mathrm{g})$ \\
\hline Controle & $2,96^{\mathrm{abc}} \pm 0,05$ \\
GGX25 & $3,23^{\mathrm{a}} \pm 0,09$ \\
GGX50 & $3,32^{\mathrm{a}} \pm 0,02$ \\
MG25 & $2,41^{\mathrm{d}} \pm 0,06$ \\
MG50 & $2,61^{\text {od }} \pm 0,03$ \\
AM100 & $3,13^{\mathrm{ab}} \pm 0,15$ \\
AM200 & $3,18^{\mathrm{a}} \pm 0,13$ \\
GGXMG & $2,98^{\mathrm{abc}} \pm 0,01$ \\
GGXAM & $3,39^{\mathrm{a}} \pm 0,29$ \\
MGAM & $2,72^{\mathrm{bod}} \pm 0,16$ \\
GGXMGAM & $2,67^{\text {od }} \pm 0,06$ \\
\hline
\end{tabular}

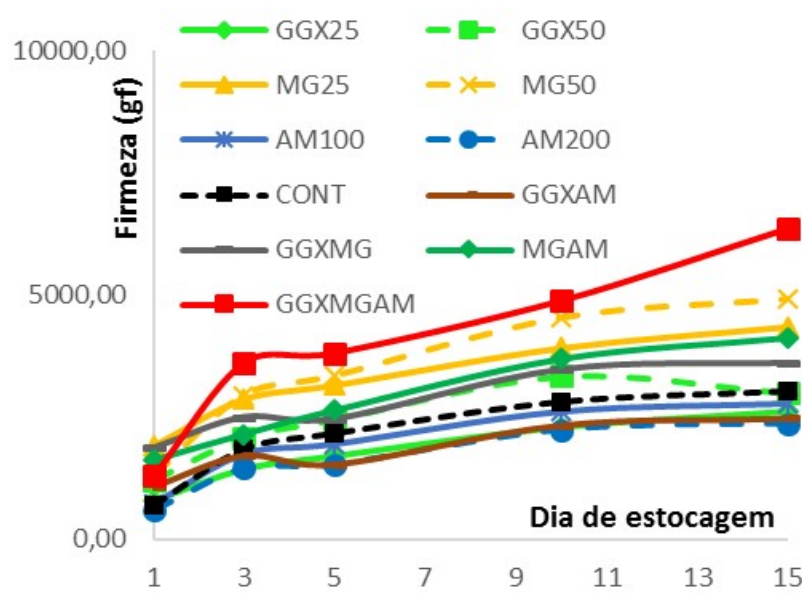

Figura 1. Textura do miolo dos pães

\section{Conclusões}

As análises sugerem que a composição do mix de farinhas pode estar retardando a retrogradação. Além disso, os monoglicerídeos estariam atuando de forma contrária ao esperado, já as gomas e a enzima contribuíram para melhores características tecnológicas ao longo do shelf life.

${ }^{1} \mathrm{HE}, \mathrm{H}$;; HOSENEY, R. C. Changes in bread firmness and moisture during long-term storage. Cereal Chemistry, v. 67, p. 603-605, 1990. ${ }^{2}$ GOMES-RUFFI, C. R., CUNHA, R. H., ALMEIDA, E. L., CHANG, Y. K. \& STEEL, C. J. Effect of the emulsifier sodium stearoyl lactylate and of the enzyme maltogenic amylase on the quality of pan bread during storage. LWT - Food Science and Technology, v.49, p.96-101, 2012. 